\title{
Aplikasi Pendidikan Kecakapan Hidup (Life Skill) pada mata Pelajaran Biologi dalam Meningkatkan Hasil Belajar Biologi Siswa Kelas VIII MTsN Model Makassar
}

\author{
Jaharudin \\ STKIP Muhammadiyah Sorong \\ jaharudin2008@gmail.com
}

Penelitian ini membahas mengenai aplikasi pendidikan kecakapan hidup (life skill), siswa belajar dalam suatu kelompok-kelompok kecil secara kolaboratif, dengan struktur kelompok yang heterogen, yang tetap memperoleh pengarahan atau bimbingan dari guru. Jadi siswa dibagi menjadi 6 kelompok kecil, kemudian diberi tugas untuk kemudian didiskusikan bersama anggota kelompoknya, di bawah pengarahan atau bimbingan dari guru.

Penelitian ini bertujuan Untuk mengetahui aplikasi pendidikan kecakapan hidup (life skill) pada mata pelajaran biologi dalam meningkatkan hasil belajar biologi siswa kelas VIII MTsN Model Makassar. Jenis penelitian yang digunakan dalam penelitian adalah penelitian ex post facto. Populasi penelitian adalah seluruh siswa MTsN Model Makassar 260 siswa, sedangkan sampelnya adalah kelas MTsN Model Makassar berjumlah 38 orang. Instrumen penelitian yang digunakan adalah tes hasil belajar siswa, lembar observasi dan pedoman wawancara. Teknik analisis data yang digunakan adalah analisis statistik deskriptif dan analisis statistik inferensial.

Dari data yang diperoleh dapat diketahui bahwa penerapan pendidikan kecakapan hidup (life skill) berpengaruh terhadap peningkatan hasil belajar siswa pada mata pelajaran biologi.

Hal ini ditunjukkan oleh hasil analisis statistik inferensial (uji statistik) diperoleh thitung= 17,33 lebih besar dari t tabel $=0,329$ pada $\alpha=0,05$ sehingga Ho diterima dan H1 ditolak

Keywords: Pendidikan Kecakapan Hidup (Life Skill), Hasil Belajar

\section{Pendahuluan}

Pendidikan memiliki peran sangat penting dalam pembangunan bangsa, kiranya tidak ada yang meragukan. Namun tentu harus dipahami, pendidikan yang mampu mendukung pembangunan adalah pendidikan yang bermutu, yaitu pendidikan yang mampu mengembangkan potensi peserta didik, sehingga yang bersangkutan mampu menghadapi dan memecahkan problema kehidupan yang dihadapinya. Namun demikian berbagai indikator menunjukkan bahwa mutu pendidikan di Indonesia masih belum meningkat secara signifikan. Dari berbagai indikator memperlihatkan bahwa pada sisi kehidupan perilaku keseharian siswa, juga banyak terjadi ketidakpuasan masyarakat. Tawuran antar siswa kini sudah menjadi berita biasa. Jika dulu tawuran diikuti siswa-siswa SMA di kota besar, kini sudah menjalar sampai ke SMP di kota kabupaten bahkan sudah merajalela kekota - kota terpelosok. Sementara itu, mereka merasa malu jika harus membantu orang tuanya sebagai petani atau pedagang.

Guru Biologi harus mampu memahami dalam menentukan tingkat kemampuan anak dalam pembelajaran materi Biologi. Pemberian materi diharapkan berjenjang dan 
berkelanjutan sesuai dengan tuntutan kurikulum. Penekanan pembelajaran pada siswa SMA pada gagasan atau pemikiran Untuk lebih mengembangkan gagasan atau pemikiran tersebut, kemampuan guru dalam membaca referensi kesejarahan mutlak diperlukan.

Demikian juga dengan aspek kecakapan hidup akan bisa dikembangkan di sekolah terutama dalam pembelajaran Biologi, manakala pembelajaran itu sendiri dapat direspons secara positif oleh anak didik. Selama ini masyarakat dan praktisi pendidikan menganggap bahwa indikator keberhasilan pembelajaran sebagai inti proses pendidikan adalah nilai ujian nasional (NUN).

Pandangan seperti itu tidak keliru, akan tetapi baru melihat salah satu indikator saja. Apabila keberhasilan hanya dipandang dari indikator itu, maka pembelajaran cenderung lebih menekankan kepada aspek kognitif semata, sehingga aspek afektif dan psikomotorik agak terabaikan. Sementara itu, sejak September tahun 2001 telah bergulir tujuan proses pembelajaran ke arah penguasaan kompetensi dasar yang bermuara pada penguasaan kecakapan hidup (life skills) yang dibutuhkan dalam kehidupan bermasyarakat. Kecakapan hidup sebagai inti dari kompetensi dan hasil pendidikan adalah kecakapan yang dimiliki seseorang untuk berani menghadapi problema hidup dan kehidupan dengan wajar tanpa merasa tertekan, kemudian secara proaktif dan kreatif mencari serta menemukan solusi sehingga akhirnya mampu mengatasinya. Maka dari latar belakang diatas lahirlah sebuah judul tentang "Aplikasi Pendidikan Kecakapan Hidup Dalam Meningkatkan Hasil Belajar Siswa Kelas VIII MTsN Model Makassar 2011/2012”

Rumusan Masalah penelitian ini adalah

1. Bagaimana bentuk aplikasi pendidikan kecakapan hidup (life skil) pada mata pelajaran biologi di kelas VIII MTsN Model Makassar?

2. Bagaimana hasil belajar siswa setelah aplikasi pendidikan kecakapan hidup (life skil) padakelas VIII MTsN Model Makassar?

3. Apakah ada pengaruh Aplikasi pendidikan kecakapan hidup terhadap peningkatan hasil belajar siswa kelas VIII MTsN Model Makassar?

Tujuan Penelitian ini adalah

a. Untuk mengetahui bagaimanakah bentuk aplikasi pendidikan kecakapan hidup (life skil) pada mata pelajaran biologi kelas VIII MTsN Model Makassar

b. Untuk mengetahui bagaimana hasil belajar siswa setelah aplikasi pendidikan kecakapan hidup (life skil) pada kelas VIII MTsN Model Makassar

c. Untuk mengetahui apakah ada pengaruh pendidikan kecakapan hidup (life skill) terhadap peningkatan hasil belajar siswa pada kelas VIII MTsN Model Makassar

\section{Tinjauan Pustaka}

\section{A. Pengertian Pendidikan Kecakapan Hidup}

Meskipun kecakapan hidup telah didefinisikan berbeda-beda, namun esensi pengertiannya sama. Menurut Brolin mendefinisikan kecakapan hidup sebagai 
kontinum pengetahuan dan kemampuan yang diperlukan oleh seseorang untuk berfungsi secara independen dalam kehidupan. Pendapat lain mengatakan bahwa kecakapan hidup adalah kecakapan sehari-hari yang diperlukan oleh seseorang agar sukses dalam menjalankan kehidupan. Kemudian pendidikan kecakapan hidup sebagai kecakapan untuk bekerja selain kecakapan untuk berorientasi ke jalur akademik. Sementara itu Tim Broad-Based Education menafsirkan kecakapan hidup sebagai kecakapan yang dimiliki seseorang untuk mau dan berani menghadapi problema hidup dan kehidupan secara wajar tanpa merasa tertekan, kemudian secara proaktif dan kreatif mencari serta menemukan solusi sehingga akhirnya mampu mengatasinya.

Dalam arti yang sesungguhnya, pendidikan kecakapan hidup memerlukan penyesuaian-penyesuaian dari pendekatan supply-driven menuju ke demand-driven. Pada pendekatan supply-driven, apa yang diajarkan cenderung menekankan pada school-based learning yang belum tentu sepenuhnya sesuai dengan nilai-nilai kehidupan nyata yang dihadapi oleh peserta didik. Pada pendekatan demand-driven, apa yang diajarkan kepada peserta didik merupakan refleksi nilai-nilai kehidupan nyata yang dihadapinya sehingga lebih berorientasi kepada life skill-based learning.

Dengan demikian, kerangka pengembagan pendidikan berbasis pendidikan kecakapan hidup idealnya ditempuh secara berurutan sebagai berikut, Pertama, diidentifikasi masukan dari hasil penelitian, pilihan-pilihan nilai, dan dugaan para ahli tentang nilai-nilai kehidupan nyata yang berlaku. Kedua, masukan tersebut kemudian digunakan sebagai bahan, untuk mengembangkan kompetensi kecakapan hidup. Kompetensi kecakapan hidup yang dimaksud harus menunjukkan kemampuan, kesanggupan, dan keterampilan untuk menjaga kelangsungan hidup dan Perkembangannya dalam dunia yang sarat perubahan. Ketiga, kurikulum dikembangkan berdasarkan kompetensi kecakapan hidup yang telah dirumuskan. Artinya, apa yang harus, seharusnya, dan yang mungkin diajarkan pada peserta didik disusun berdasarkan kompetensi yang telah dikembangkan. Keempat, penyelenggaraan pendidikan kecakapan hidup perlu dilaksanakan dengan jitu agar kurikulum berbasis kecakapan hidup dapat dilaksanakan secara cermat. Menurut konsep di atas, kecakapan hidup adalah kemampuan dan keberanian untuk menghadapi problema kehidupan, kemudian secara proaktif dan kreatif mencari dan menemukan solusi untuk mengatasinya. Pendidikan berorientasi kecakapan hidup bagi peserta didik adalah sebagai bekal dalam menghadapi dan memecahkan problema hidup dan kehidupan, baik sebagai pribadi yang mandiri, warga masyarakat, maupun sebagai warga negara. Apabila hal ini dapat dicapai, maka ketergantungan terhadap ketersediaan lapangan pekerjaan, yang berakibat pada meningkatnya angka pengangguran, dapat diturunkan, yang berarti produktivitas nasional aka meningkat secara bertahap menurut konsep pendidikan kecakapa hidup dapat digambrkan sebagai berikut:

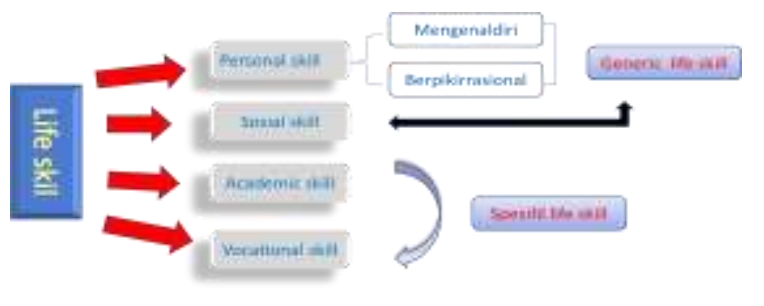


Gambar 1. Konsep pendidikan kecakapan hidup (life skill)

\section{B. Pengertian Hasil Belajar}

Hasil belajar didefenisikan sebagai terjadinya suatu perubahan ditinjau dari tiga aspek yakni: aspek kognitif (penguasaan intelektual), aspek afektif (berhubungan dengan sifat dan nilai), dan aspek psikomotorik (kemampuan/ keterampilan bertindak atau berprilaku) ketiga aspek tersebut tidak berdiri sendiri, tapi merupakan satu kesatuan yang tidak terpisahkan bahkan membentuk hubungan yang hirarki.

Berdasarkan pengertian hasil belajar yang telah dipaparkan di atas, maka dapat dipahami bahwa hasil belajar merupakan suatu gambaran dari penguasaan kemampuan peserta didik yang dicapai setelah melakukan proses belajar mengajar, Bertolak dari pengertian di atas, lebih lanjut dijelaskan bahwa unsur-unsur dalam hasil belajar meliputi 3 aspek sebagai berikut:

\section{Prinsip-prinsip Belajar}

Dalam mengerjakan sesuatu seseorang harus mempunyai prinsip-prinsip tertentu, begitu juga halnya dengan belajar. Untuk menertibkan diri dalam belajar harus mempunyai prinsip sebagaimana yang diketahui prinsip belajar memang kompleks tetapi dapat juga dianalisis dan diperinci dalam bentuk-bentuk prinsip atau azas belajar sebagaimana yang dinyatakan oleh Oemar Hamalikmeliputi: Belajar adalah suatu proses aktif dimana terjadi hubungan mempengaruhi secara dinamis antara siswa dan lingkungan. Belajar harus senantiasa bertujuan, searah dan jelas bagi siswa.Belajar yang paling efektif apabila didasari oleh dorongan motivasi yang murni dan bersumber dari dalam diri siswa itu sendiri.Senantiasa ada hambatan dan rintangan dalam belajar, karena itu siswa harus sanggup menghadapi atau mengatasi secara tepat.Belajar memerlukan bimiingan baik itu dari guru atau tuntutan dari buku pelajaran itu sendiri.Jenis belajar yang paling utama ialah belajar yang berpikiran kritis, lebih baik daripada pembentukan kebiasaan-kebiasaan mekanis.Cara belajar yang paling efektif adalah dalam pembentukan pemecahan masalah melalui kerja kelompok asalkan masalah tersebut disadari bersama.

Belajar memerlukan pemahaman atas hal-hal yang dipelajari, sehingga diperoleh pengertian-pengertian.Belajar memerlukan latihan dan ulangan, agar apa-apa yang dipelajari dapat dikuasai.Belajar harus disertai dengan keinginan dan kemauan yang kuat untuk mencapai tujuan.Belajar dianggap berhasil apabila si pelajar telah sanggup menerapkan dalam prakteknya.

Banyak siswa yang telah belajar dengan giat tetapi usahanya itu tidak memberikan hasil yang diharapkan, dan sering kali mengalami kegagalan, bekerja keras belum tentu menjamin seseorang dapat belajar dengan berhasil.Di samping itu seorang siswa perlu memperhatikan syarat-syarat dapat belajar secara efesien atau belajar dengan baik. Di antara syarat-syarat tersebut adalah sebagai berikut:Kesehatan jasmani, badan yang sehat berarti tidak mengalami gangguan penyakit tertentu cukup dengan vitamin dan seluruh fungsi badan berjalan dengan baik.Rohani yang sehat. 


\section{METODOLOGI PENELITIAN}

Jenis penelitian ini adalah penelitian ex post facto, menurut Emzir penelitian ex post facto merupakan eksperimen yang juga menguji hipotesis tetapi tidak memberikan perlakuan-perlakuan tertentu karena sesuatu sebab kurang etis untuk memberikan perlakuan atau memberikan manipulasi. Biasanya karena alasan etika manusiawi, atau gejala/peristiwa tersebut sudah terjadi dan ingin menelusuri faktor-faktor penyebabnya atau hal-hal yang mempengaruhinya.

Dalam penelitian ini, peneliti tidak memberikan perlakuan secara khusus karena untuk menemukan penyebab yang memungkinkan perubahan prilaku. Gejala atau fenomena yang disebabkan oleh suatu peristiwa, perilaku atau hal-hal yang menyebabkan perubahan pada variable terikat yang secara keseluruhan sudah terjadi sejakditerapkannya Pendidikan kecakapan hidup sebagai sebab meningkatnya Hasil belajar siswa kelas VIII MTsN Model Makassar 2011/2012.

Jadi populasi dalam penelitian ini adalah kelas VIII MTsN Model Makassar 260 siswa, Teknik pengambilan sampel dalam penelitian ini adalah Random Sampling, teknik ini bertujuan untuk mengambil sampel secara objektif karena setiap unit yang menjadi anggota populasi mempeunyai kesempatan yang sama untuk dipilih menjadi anggota sampel. Jadi sampel dalam penelitian ini adalah kelas $\mathrm{VIII}_{1} \mathrm{MTsN}_{\mathrm{N}}$ Model Makassar 38 siswa.

Hipotesis pada penelitian ini adalah terdapat pengaruh aplikasi pendidikan kecakapan hidup (life skill) dalam peningkatan hasil belajar siswa kelas VIII MTsN Model Makassar.

\section{HASIL DAN PEMBAHASAN}

\section{Deskripsi Bentuk Penerapan Pendidikan Kecakapan Hidup di Kelas VIII MTsN Model Makassar}

Berdasarkan penelitian yang telah dilakukan di MTsN Model Makassar penulis memperoleh data dari intrumen pedoman observasi tentang penerapan pendidikan kecakapan hidup yang diterapkan dalam pembelajaran Biologi di kelas VIII 1 MTsN Model Makassar. Adapun yang menjadi sobjek observasi adalah hal-hal yang menjadi indikator penerapan pendidikan kecakapan hidup, yang dalam hal ini menyangkut kecakapan akademik. Data hasil observasi tersebut adalah sebagai berikut:

Tabel 4.0

Tabel skor hasil observasi penerapan pendidikan kecakapan hidup siswa kelasVIII 1 MTsN Model Makassar

\begin{tabular}{|c|l|c|c|}
\hline No & $\begin{array}{l}\text { Nama } \\
\text { Siswa }\end{array}$ & Skor & $\begin{array}{l}\text { Konversi } \\
\text { ke skala } \\
100\end{array}$ \\
\hline 1 & $\mathrm{Rb}$ & 38 & 95 \\
\hline 2 & $\mathrm{BM}$ & 25 & 62,5 \\
\hline
\end{tabular}




\begin{tabular}{|l|l|c|c|}
\hline 3 & NR & 30 & 75 \\
\hline 4 & SM & 38 & 95 \\
\hline 5 & DW & 38 & 95 \\
\hline 6 & AA & 35 & 87,5 \\
\hline 7 & SF & 33 & 82,5 \\
\hline 8 & F & 33 & 82,5 \\
\hline 9 & NA & 20 & 50 \\
\hline 10 & MR & 33 & 82,5 \\
\hline 11 & DA & 25 & 62,5 \\
\hline 12 & AH & 20 & 50 \\
\hline 13 & RR & 30 & 75 \\
\hline 14 & SS & 38 & 95 \\
\hline 15 & MM & 37 & 92,5 \\
\hline 16 & OA & 37 & 92,5 \\
\hline 17 & RF & 37 & 92,5 \\
\hline 18 & MH & 30 & 75 \\
\hline 19 & SH & 34 & 85 \\
\hline 20 & MN & 30 & 75 \\
\hline 21 & HB & 38 & 95 \\
\hline 22 & RK & 38 & 95 \\
\hline 23 & FR & 36 & 90 \\
\hline 24 & QR & 36 & 90 \\
\hline 25 & MF & 36 & 90 \\
\hline 26 & FA & 25 & 62,5 \\
\hline 27 & AF & 25 & 70 \\
\hline 28 & LM & 28 & 95 \\
\hline 29 & NF & AI & \\
\hline 30 & DT & 39 & \\
\hline 31 & Muh. & TaG & 39 \\
\hline 32 & AI & 39 \\
\hline
\end{tabular}




\begin{tabular}{|c|l|c|c|}
\hline 33 & DF & 37 & 92,5 \\
\hline 34 & GT & 30 & 70 \\
\hline 35 & SB & 38 & 95 \\
\hline 36 & MA & 39 & 97,5 \\
\hline 37 & ID & 34 & 85 \\
\hline 38 & AN & 38 & 95 \\
\hline
\end{tabular}

Sumber: Hasil olah data dari lembar observasi penerapan pendidikan kecakapan hidup siswa kelas VIII 1 MTsN Model Makassar

a. Menghitung rata - rata (mean)

Rata-rata (mean) dapat dihitung dengan menggunakan rumus sebagai berikut:

$$
\bar{X}=\frac{\Sigma f_{i} x_{i}}{\Sigma f_{i}}
$$

\section{Keterangan:}

$$
\begin{aligned}
& \bar{X}=\text { Skor rata-rata } \\
& f_{i}=\text { Jumlah skor keseluruhan } \\
& x_{i}=\text { Titik tengah }
\end{aligned}
$$

Untuk menghitung rata-rata (mean) terlebih dahulu menghitung rentang nilai $(\mathrm{R})$, banyak kelas interval $(\mathrm{K})$, dan panjang kelas $(\mathrm{P})$ sebagai berikut:

b. Rentang nilai $(\mathrm{R})$

Rentang Nilai yang dilambangkan dengan $\mathrm{R}$ dapat dihitung dengan rumus.

$$
\begin{array}{ll}
\text { Skor tertinggi }(\mathrm{Xt}) & =39 \\
\text { Skor terendah }(\mathrm{Xr}) & =10 \\
\text { Jumlah sampel }(\mathrm{n}) & =38 \\
\mathrm{R}=\mathrm{Xt}-\mathrm{Xr}+1 & \\
\mathrm{R}=39-11=28 &
\end{array}
$$

c. Jumlah kelas interval (K)

Banyak kelas interval dapat dihitung dengan menggunakan rumus sebagai berikut: $\mathrm{K}$ $=1+(3,3) \operatorname{losg} \mathrm{n}$

Maka banyak kelas interval adalah

$$
\begin{aligned}
\mathrm{K}=1 & +(3,3) \log \mathrm{n} \\
& =1+(3,3) \log 38 \\
& =1+5,18 \\
& =5,19(5)
\end{aligned}
$$

a. Panjang Kelas Interval $(\mathrm{P})$

Panjang kelas interval (P), yaitu hasil bagi rentang dengan banyaknya kelas. Dalam hal :

$$
\mathrm{P}=\frac{R}{K}
$$




$$
\begin{aligned}
& =\frac{28}{5} \\
& =5,6
\end{aligned}
$$

Untuk memudahkan menghitung nilai rata-rata (mean), maka dibuat tabel distribusi frekuensi sebagai berikut:

\section{Tabel 4.1}

Distribusi frekuensi untuk menghitung nilai rata-rata (mean)

\begin{tabular}{|c|c|c|c|}
\hline Interval & $\boldsymbol{F i}$ & $X i$ & $f i X i$ \\
\hline $10-15$ & 0 & 12,5 & 0 \\
\hline $16-21$ & 2 & 18,5 & 37 \\
\hline $22-27$ & 4 & 24,5 & 98 \\
\hline $28-33$ & 10 & 30,5 & 305 \\
\hline $34-39$ & 22 & 36,5 & 803 \\
\hline Jumlah & 38 & 122,5 & 1243 \\
\hline
\end{tabular}

Sehingga nilai rata-rata (mean), dapat diperoleh sebagai berikut:

$$
\begin{aligned}
& \bar{X}=\frac{\Sigma f_{i} x_{i}}{\Sigma f_{i}} \\
& =\frac{1243}{38} \\
& =32,71
\end{aligned}
$$

Tabel 4.3

Tabel penolong untuk menghitung uji korelasi siswa kelas VIII 1 MTsN Model Makassar

\begin{tabular}{|c|c|c|c|c|c|}
\hline Interval & $X$ & $Y$ & $X Y$ & $X^{2}$ & $Y^{2}$ \\
\hline $65-70$ & 0 & 11 & 0 & 0 & 121 \\
$71-76$ & 2 & 4 & 8 & 4 & 16 \\
$77-82$ & 4 & 7 & 28 & 16 & 49 \\
$83-88$ & 10 & 4 & 40 & 100 & 16 \\
$89-95$ & 22 & 12 & 264 & 484 & 144 \\
\hline
\end{tabular}




\begin{tabular}{|l|l|l|l|l|l|}
\hline Jumlah & 38 & 38 & 340 & 604 & 346 \\
\hline
\end{tabular}

a. Penetapan regresi linear sederhana

untuk menghitung persamaan regresi linear sederhana terlebih menghitung nilai $b$ dan a dengan rumus sebagai berikut:

menghitung rumus $b$

$$
\begin{aligned}
b & =\frac{n \sum_{i=1}^{n} x_{i} y_{i}-\left(\sum_{i=1}^{n} x_{i}\right)\left(\sum_{i=1}^{n} y_{i}\right)}{\mathrm{n} \sum_{i=1}^{n} x_{i}^{2}-\left(\sum_{i=1}^{n} x_{i}\right) 2} \\
& =\frac{38 \times 340-(38)(38)}{38 \times 604-\left(38^{2}\right)} \\
& =\frac{12920-1444}{22952-1444} \\
& =\frac{11476}{21508} \\
& =0,52
\end{aligned}
$$

Menghitung rumus a

$a=\frac{\sum_{i=1}^{n} Y i}{n}-b \frac{\sum_{i=1}^{n} X i}{n}$

$a=\frac{38}{5}-\left(0,52 \frac{38}{5}\right)$

$=7,6-(0,52 \times 7,6)$

$=76-3,95$

$=3,65$

Jadi persamaan regresi linear sederhana adalah

$\hat{Y}=\mathrm{a}+\mathrm{bX}$

$=3,65+0,52 \mathrm{X}$ 
b. Uji korelasi

Rumus korelasi pearson product moment:

$$
\begin{aligned}
& r X Y=\frac{N \sum X Y-\left(\sum X\right)\left(\sum \mathrm{Y}\right)}{\sqrt{\left\{\mathrm{N} \sum X^{2}-\left(\sum X\right)^{2}\right\}\left\{\mathrm{N} \sum \mathrm{Y}^{2}-\left(\sum \mathrm{Y}\right)^{2}\right\}}} \\
& \begin{array}{c}
=\frac{38 \times 340-(38)(38)}{\sqrt{\left\{38 \times 604-(38)^{2}-\left\{38 \times 38-(38)^{2}\right\}\right.}} \\
\sqrt{\sqrt{\{22952-1444\}-(13148-1444}}
\end{array} \\
& =\frac{11476}{\sqrt{21508-11704}} \\
& =\frac{11476}{\sqrt{9805}} \\
& =\frac{11476}{99.02} \\
& =115,89 \\
& \text { Syx }=\sqrt{\frac{\sum y^{2-a \cdot \Sigma^{Y-b \cdot \Sigma X Y}}}{n-2}} \\
& =\sqrt{\frac{346-3,65 \times 38-0,52 \times 340}{38-2}} \\
& =\sqrt{\frac{346-3,65 \times 38-176,8}{36}}
\end{aligned}
$$




$$
\begin{aligned}
& =\sqrt{\frac{346-138,7-176,8}{36}} \\
& =\sqrt{\frac{207,3-176,8}{36}} \\
& =\sqrt{\frac{30,5}{36}} \\
& =\sqrt{0,84} \\
& \text { Syx }=0,91
\end{aligned}
$$

2). Untuk koefisien regresi b (pendugaan b), kesalahan bakunya dirumuskan:

$$
\begin{array}{rl}
\mathrm{Sb} & =\frac{S y x}{\sqrt{\sum X^{2}}-\frac{\left(\sum X\right)^{2}}{n}} \\
& =\frac{0,91}{\sqrt{604-\frac{(38)^{2}}{38}}} \\
& =\frac{0,91}{\sqrt{604-38}} \\
& =\frac{0,91}{\sqrt{566}} \\
& =\frac{0,91}{23,79} \\
=0,03 & \mathrm{Sb}=0,03
\end{array}
$$

Taraf nyata $(\mathrm{a})=5 \%=0,03$

\section{Hipotesis Penelitian}

Pengujian hipotesis digunakan untuk mengetahui dugaan sementara yang dirumuskandalam hipotesis penelitian dengan menggunakan uji t, dengan langkah-langkah pengujian sebagai berikut:

(a) Menentukan forrnulasi hipotesis

$$
\begin{aligned}
& \mathrm{H} 0: \mathrm{B}=\mathrm{B} 0 \\
& \mathrm{H} 1: \mathrm{B} \neq \mathrm{B} 0
\end{aligned}
$$


(b). Menentuakn taraf nyata (1) dan nilai t tabel

taraf nyata dan nilai t tabel ditentukan dengan derajad bebas $(\mathrm{db})=\mathrm{n}-2$

$$
\begin{array}{rl} 
& \mathrm{a}=5 \%=0,05(\mathrm{a} / 2=0,320) \\
\mathrm{db} & =\mathrm{n}-2 \\
& =38-2 \\
& =36 \\
\mathrm{t} & 0,320(36)=0,329
\end{array}
$$

(c). Menentukan kriterian pengujian hipotesis

i). Ho diterima apabila thitung $<$ dari t tabel

ii). $\mathrm{H}_{1}$ ditolak apabila t hitung $>$ dari $\mathrm{t}$ tabel

(d). Menentukan nilai uji statistik

$$
\begin{aligned}
& \beta=\text { Untuk parameter } \\
& \text { to }=\frac{b-\beta}{S b} \\
& \text { to }=\frac{0,52-0}{0,03} \\
& \text { to }=\frac{0,52}{0,03} \\
& =17,33
\end{aligned}
$$

Berdasarkan hasil analisis data di atas, tampak bahwa nilai t hitung 17,33 lebih besar dari t table $=0,329$. Dengan demikian hipotesis Ho diterima, sedangkan $\mathrm{H}_{\mathrm{i}}$ ditolak .

Berarti dalam mengaplikasikan pendidikan kecakapan hidup (life skill) berpengaruh hasil belajar kelas VIII 1 MTsN Model Makassar jadi dalam penerapan pendidikan kecakapan hidup (life skill) dapat meningkatkan hasil belajar siswa secara signifikan dengan melihat data yang telah dianalisis.

\section{Hasil dan Pembahasan}

Berdasarkan analisis data di atas dan ditinjau langsung ke lapangan maka pada kajian ini dikemukakan mengenai pembahasan hasil penelitian adalah sebagai berikut:

Hasil analisis deskiptif menunjukkan bahwa tanggapan siswa melalui penerapan pendidikan kecakapan hidup (life skill) pada mata pelajaran biologi bersifat positif, hal ini dapat dilihat dari hasil belajar mengenai minat, motivasi dan kemampuan berada pada kategori baik, artinya siswa termotivasi belajar biologi dengan adanya penerapan pendidikan kecakapan hidup (life skill) sehingga sangat berpengaruh pada kemampuan siswa dalam memahami pelajaran, dimana siswa mampu mengungkapkan gagasangagasannya pada proses pembelajaran karena adanya rasa bertanggung jawab dalam diri sendiri maupun untuk masyarakat disekitarnya. Oleh karena itu penerapan pendidikan kecakapan hidup (life skill) sangat mengdukung terhadap peningkatan hasil belajar siswa. Sejalan dengan hasil penelitian di atas dalam teori penerapan pendidikan kecakapan hidup (life skill) mengatakan bahwa pada sekolah formal khususnya sangat membantu bila diterapkan pendidikan kecakapan hidup (life skill) supaya perserta didik agar memiliki kecakapan-kecakapan atau ketrampilan untuk kebutuhan dalam kehidupan nyata, sebab tanpa adanya keterampilan yang dimiliki oleh siswa maka lahirlah asumsi-asumsi pada lembaga-lembaga pendidikan formal tidak berhasil memberikan efek positif dalam kehidupan bermasyarakat. Harapan yang sangat besar dalam dunia pendidikan di masa kini agar mampu melihat kondisi peserta didik dalam kehidupan bermasyarakat kini 
menjadi bahan pembicaraan karena siswa-siswi tidak mampu memaknai proses pelajaran disekolahnya yang mengakibatkan terjadi tawuran, bahkan mengkonsumsi bahan-bahan terlarang oleh pemerintahan apalagi dalam kehidupan beragama, oleh karena itu pendidikan mampu memberikan efek positif dalam pertumbuhan dan perkembangan siswa.

Dalam pembelajaran biologi sangat baik ketika proses belajar mengajar diterapkan penerapan pendidikan kecakapan hidup (life skill)karena pelajaran biologi membutuhkan siswa mampu memecahkan permasalahan yang muncul dalam kehidupan, misalnya pelajaran ekosistem yang didalam siswa-siswa dituntut agar mampu memberikan solusi terbaik untuk kelangsungan makhluk hidup.

\section{Kesimpulan dan Saran}

5.1. Kesimpulan

A. Hasil penerapan pendidikan kecakapan hidup (life skill) pada mata pelajaran biologi di Kelas VIII 1 MTsN Model Makassar berada pada kategori baik dengan persentase 26,31 persen, dari 38 siswa dan skor rata-rata 32,71 jika dimasukkan kedalam tabel interval berada pada kelas $28-33$.

B. Hasil belajar siswa pada mata pelajaran biologi di Kelas VIII 1 MTsN Model Makassar berada pada kategori tinggi dengan persentase 57,89 persen dari 38 siswa dan nilai rata-rata 79,81 jika di masukkan kedalam tabel interval berada pada Kelas $65-84$.

C. Terdapat pengaruh peningkatan hasil belajar siswa pada mata pelajaran biologi di Kelas VIII 1 MTsN Model Makassar yang menerapkan pendidikan kecakapan hidup (life skill) Hal ini ditunjukkan oleh hasil analisis

\section{a. Saran}

A. Pemberian penerapan pendidikan kecakapan hidup (life skill) layak dipertimbangakan sebagai wacana baru dalam pendidikan formal pada mata pelajaran biologi

B. Seorang guru mata pelajaran biologi hendaknya menerapkan pendidikan kecakapan hidup (life skill), sehingga akan berpengaruh dalam peningkatan hasil belajar siswa

C. Disarankan kepada peneliti untuk dapat melanjutkan dan mengembangkan penelitian yang sejenis, agar dapat dapat meneliti lebih mendalam lagi mengenai penerapan pendidikan kecakapan hidup (life skill)pada mata pelajaran biologi.

\section{Daftar Pustaka}

Admin.2007. Pendidikan Mengenal Life Skill. Tersedia:

http://www.smp1bojonegoro.-nrt/cetak.php?id=158. Diakses pada :Sabtu20 Februari 2010.

Andriati, M. 2010. "Aplikasi Pendidikan Kecakapan Hidup (Life Skills) Pada Mata Pelajaran Ilmu Pengetahuan Alam Untuk Kecakapan Generik di SMP AL-Islam 1 Surakarta Tahun Pelajaran 2009/2010”.Skripsi. FKIP UMS (Tidak Diterbitkan)

Anonim.2005. Pedoman Integrasi Life Skills Dalam Pembelajaran. 
Jakarta:Dirjen KAI Depag.

Anwar. 2004. Pendidikan Kecakapan Hidup (Life skill education). Bandung :Alfabeta.

Arikunto, Suharsimi, 2010. Prosedur Penelitian (Suatu Pendekatan Praktek). Bandung: Rineka Cipta Bandung

Asmani. 2009. “Sekolah Life Skills” Lulus Siap Kerja!.Yogyakarta: DIVA Press.

Brolin, D.E. 1989. Life Centered Career Education: A Competency Based Apprc

Departemen Agama. 2005. RI, AL-JUMANATUL ALI “ Al-Qur'an dan Terj Bandung: J-ART

Djamarah, Syaiful Bachri, 2002. Strategi Belajar Mengajar Cet III. Jakarta: Rineka Cipta

Depdikbud Dikdasmen, 1997. Petunjuk Pelaksanaan Proses Belajar Mengajar.

Jakarta: Depdikbud.

Dimyati, M.,\& Mudjiono. 1999. Belajar dan Pembelajaran. Depdikbud.

Jakarta: PT Rineka Cipta

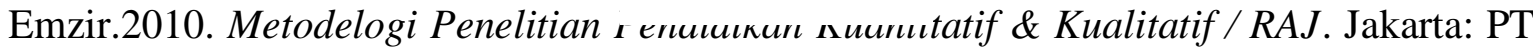
Rajagrafindo Persada

Hasibuan, J.J. 1988. Proses Belajar Mengajar Ketrampilan Dasar Pengajaran Mikro. Bandung: Remadja Karya.

Roestiyah N,K. 2008. Pendekatan Dalam Proses Pembelajaran.jakarta: Rineka Cipta.

Rusman.Model-Model Pembelajaran (Mengembangkan Profesionalisme Guru). Jakarta. Raja Grafindo Persada. 2010

Satori. D. 2002. “Implementasi Life Skills dalam Konteks Pendidikan di Sekolah".jurnal Pendidikan dan Kebudayaan. Vol 8, No 034 (hal 23-37).

Slamet PH. 2002. "Pendidikan Kecakapan Hidup Konsep Dasar". Jurnal p Kebudayaan. Balitbang Diknas. Vol 8, No 037

(hal 541 -561) Balitbang Diknas.

...... 2002. Pendidikan Kecakapan Hidup di Sekolah Lanjutan Tingkat Pertama: Konsep dan Pelaksanaan. Jakarta. Direktorat Sekolah Lanjutan Tingkat Pertama.

Sugiyono. 2010. Metode Penelitian Pendidikan (pendekatan kuantitatif, kualitatif, ada R ,D)

Sukmadinata, N.S. 2004. Kurikulum dan Pembelajaran Kompotensi. Bandung: PT. Remaja Rosdakarya

Moerseptyo, Subana. 2000. Statistik Pendidikan. Bandung: CV Pustaka Setia

Wina sanjaya, 2010.Strategi Pembelajaran Berorientasi Standar Proses Pendidikan. Jakarta: Kencana. 